\title{
The Process of Shaping Place in Residential Area Towards Livable Neighbourhood
}

\author{
Dwira Nirfalini Aulia, Beny OY Marpaung, Wahyuni Zahrah \\ Faculty of Engineering Department of Architecture, \\ University of Sumatera Utara, Indonesia \\ dwira.nirfalini@usu.ac.id
}

\begin{abstract}
The process of shaping place in the residential area occurs on sustainability. Although in the area of planned settlement, changes always take place in the process of shaping place. This study was conducted to observe the changes and how the process can increasing Livable Neighborhood. The variables of change are management strategies, public areas, and activity generators, planning strategies, and design strategies. The results found that it takes cooperation between housing stakeholders to create a livable neighborhood.
\end{abstract}

Keywords: place shaping; residential area; livable neighbourhood

eISSN 2398-4279 @ 2018 . The Authors. Published for AMER ABRA cE-Bs by e-International Publishing House, Ltd., UK. This is an open access article under the CC BY-NC-ND license (http://creativecommons.org/licenses/by$n c-n d / 4.0 /$ ). Peer-review under responsibility of AMER (Association of Malaysian Environment-Behaviour Researchers), ABRA (Association of Behavioural Researchers on Asians) and CE-Bs (Centre for EnvironmentBehaviour Studies), Faculty of Architecture, Planning \& Surveying, Universiti Teknologi MARA, Malaysia.

DOI: https://doi.org/10.21834/ajqol.v3i13.175 


\subsection{Introduction}

The growth of urban population in developing countries such as Indonesia has happened as a result of urbanization. The symptoms of urban growth like this raise the question, how can the city's growth and development be sustained? How can the citizen continue to grow and fulfill the needs for food, homes, jobs and safety? The livable neighborhood will affect the quality of life. So, to create a high quality of life, we should make some efforts to establish a livable community.

The aim of the research is to explore the process of shaping place in a planned residential area. The exploration needs to be done to improve the livable neighborhoods. There are three parts of the paper. The first part describes the background, purpose of the study and literature review. The second part described research methods and the implementation of investigation's process. The last part is describing the results, discussion, analysis and conclusions of the study. The objective of the research is to explore the process of forming the planned residential area as an effort to increasing livable neighborhood in the future.

\subsection{Literature Review}

\subsection{Livable Neighborhood}

The design of residential environment closely linked to the quality of life. Every concept design of residential environment will form a different neighborhood quality of life. The formation of place as the spatial space where human activity becomes an important part in creating the livable community. Some researchers have different opinions about factors that affect the formation of a livable neighborhood. For example, the scale factor of public space in the residential area (McCann, 2008) and the factors of housing density and mitigate disasters (Pacione, 1990). The factor of concept design of built environment (Bajunid et al, 2012), and the factor of human comfort and capabilities within living environments (Conteh \& Oktay, 2016) also the factors will affects livable neighbourhood.

The research of livable neighborhood has done with the goal to establish an ideal residential environment and achieving a high quality of life for its residents. Based on the residential satisfaction will arrange the framework increasing livable neighborhood. The description need of residential environment related to safety environmental (Sakip et al., 2013; Cinar \& Cubukcu, 2013; Okunola \& Amole, 2013), aspects of residential facility (Benefield, 2009) and the aspect of housing location (Kim et al., 2005).

Some studies show an interest in 'place shaping' as a way to create a livable neighborhood. Place shaping demands a robust integration of economic, social, cultural and environmental goals. Place shaping is about serving the needs of diverse communities (Carmona, 2014). That is why in this study requires a description about the choice of residential environment.

\subsection{The process of shaping place}

The process of developing the place in a residential area involving various professions. They transcended the public and private modes of development and all forms of partnership in 
between at different times and in different places in the neighborhood. There are three stages in the process of shaping area. (Carmona, 2014). The first stage is the identification of the history and tradition of the site. The second phase conducted an active process in place, such as the establishment of the design, construction, the use and management of the area and maintaining the site. The third phase is the establishment a synergy between stakeholders. The process of shaping area will continues and sustainable. At the stage of identification the tradition of the site, it will take the identity of a place in advance.

Several studies conducted to establish the identity of the area is done by forming branding first. Place branding is a key aspect of improving and promoting area (Hanna \& Rowley, 2013). In some cases, the process of shaping place, before the second stage, will need the meeting with stakeholders for the socialization of physical implementation development. Caneparo \& Bonavero (2016) mentions the scene by the incubators co-creative process and system. This process will assist the implementation of the third stage is the synergy between stakeholders. The results of the socialization can decide some strategic planning and strategic design on physical development. The decisions to manage the behavior in using public area more sustainable, such as sidewalk pattern, walkability (Shamsuddin et al., 2013), connectivity to public spaces, Commercial Street, and parks in a residential neighborhood (Anuar \& Saruwono, 2013) will help to increase livable community.

\subsection{Methodology}

The research of liveable neighborhood has done with different approaches and methods. Such as evaluating and ranking the livability based on occupant satisfaction (Kozaryn, 2013), assessing the residential area with the method of analytic hierarchy process (Chiang \& Liang, 2013), and perform predictive factors increasing the livability based on the perception by occupants (der Pas et al., 2015). The evaluation used because the objective of the research is to get the formation of the livable neighborhood to get an idea of the occupant's needs of the residential environment. This research is a descriptive exploratory study with quantitative and qualitative approach

The evaluation conducted in two planned housing in Medan city, namely Taman Setia Budi Indah Estate and Johor Indah Permai Estate. Both housing estate is developed by private developers and has inhabited for more than 30 years. After so long occupied, neighborhood conditions are still right with property values still increased. Each housing has a public space that also serves as a generator activity. The place which remains livable at Taman Setia Budi Indah is the commercial center, while at Johor Indah Permai estate, is the mosque in the housing area. The observation of researchers at both of the generator activity becomes the basis on which the questionnaire distributed. The surveys conducted for three months in the afternoon and the end of the week. The distribution of the questionnaires based on the time when public space is in the most crowded area. Primary data collected by distributing questionnaires to residents to find out the established of place attachment in an open space and the description of residents need about the living environment. Then made the observations and interviews related to estate planning component to get an idea about the condition of each residential environment. The changing dynamics of social housing 
residents led to the changing of livable neighborhood indicator.

\subsection{Results and Discussion}

The questionnaires distributed to visitors of public spaces in the residential area. 64 respondents returned the survey in Taman Setia Budi Indah, while in Johor Indah Permai housing only 32 respondents. The distribution of questionnaires carried out when the public space crowded by residents, such as in the afternoon or holidays. From the allocation of the survey obtained the following results

The questionnaires distributed to visitors of public spaces in the residential area. 64 respondents returned the survey in Taman Setia Budi Indah, while in Johor Indah Permai housing only 32 respondents. The distribution of questionnaires carried out when the public space crowded by residents, such as in the afternoon or holidays. From the allocation of the survey obtained the following results

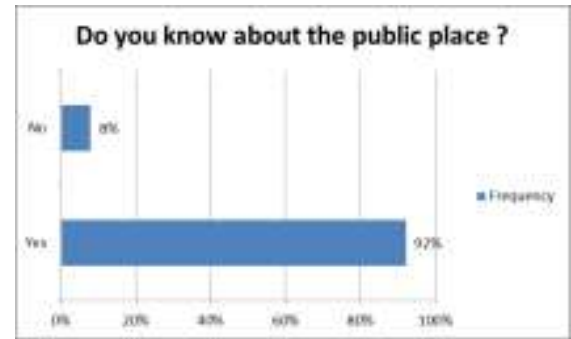

Figure 1. Know about commercial center

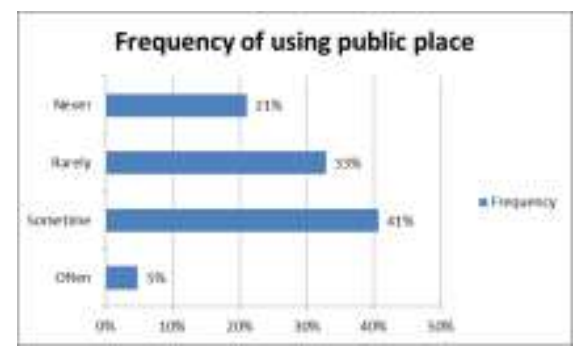

Figure 2. Frequency of using commercial center

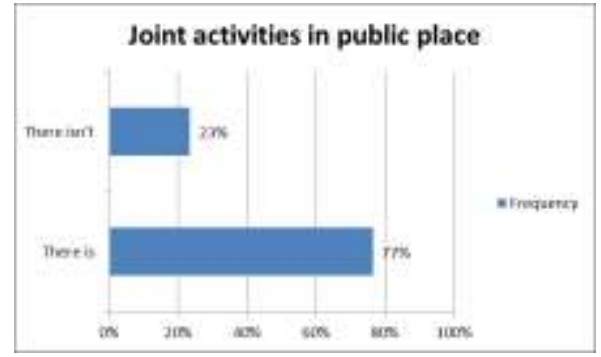

Figure 3. Joint activities

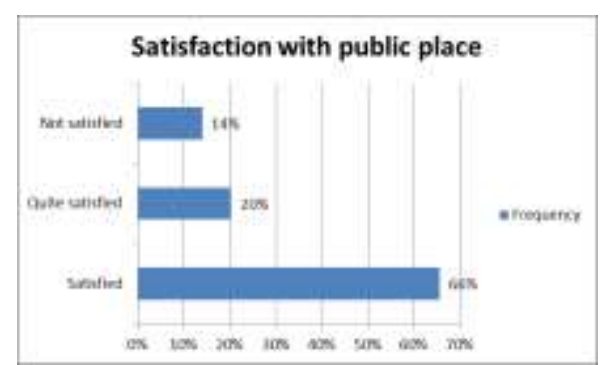

Figure 4. Satisfaction with commercial center

In Figure 1 is seen almost $92 \%$ of respondents knew about the business center in Taman Setia Budi Indah. Although only $5 \%$ of respondents who frequently use these place (Figure 2). There are $41 \%$ of respondents who sometimes take advantage of the location and $33 \%$ 
of respondents rarely use the environmental center. Both groups of the user has the potential for increased the involvement in the commercial center of the neighborhood. To increase the use of business centers will need the changes in management and development of the place. Some activities regularly held in this area are a motor vehicle exhibition, book display and a variety of foods.

The residents should be involved in organizing activities; it appears that approximately $77 \%$ of the people do activities together, such as social interaction, eating, drinking, etc. (Figure 3). Occupants only serve as a consumer in the commercial center and not as a producer. Shirotsuki et al. (2010) suggested developing the concept of sense of place in public spaces so that residents also participate in proposed the policy for the residential area. In Figure 4 appears that there are $66 \%$ of respondents who were satisfied with the facilities provided at the commercial center, followed by $20 \%$ feel quite satisfied and only $14 \%$ were dissatisfied. This condition illustrates that the existing commercial centers already meet the needs of residents although the process of shaping place can still be improved the maintenance further.

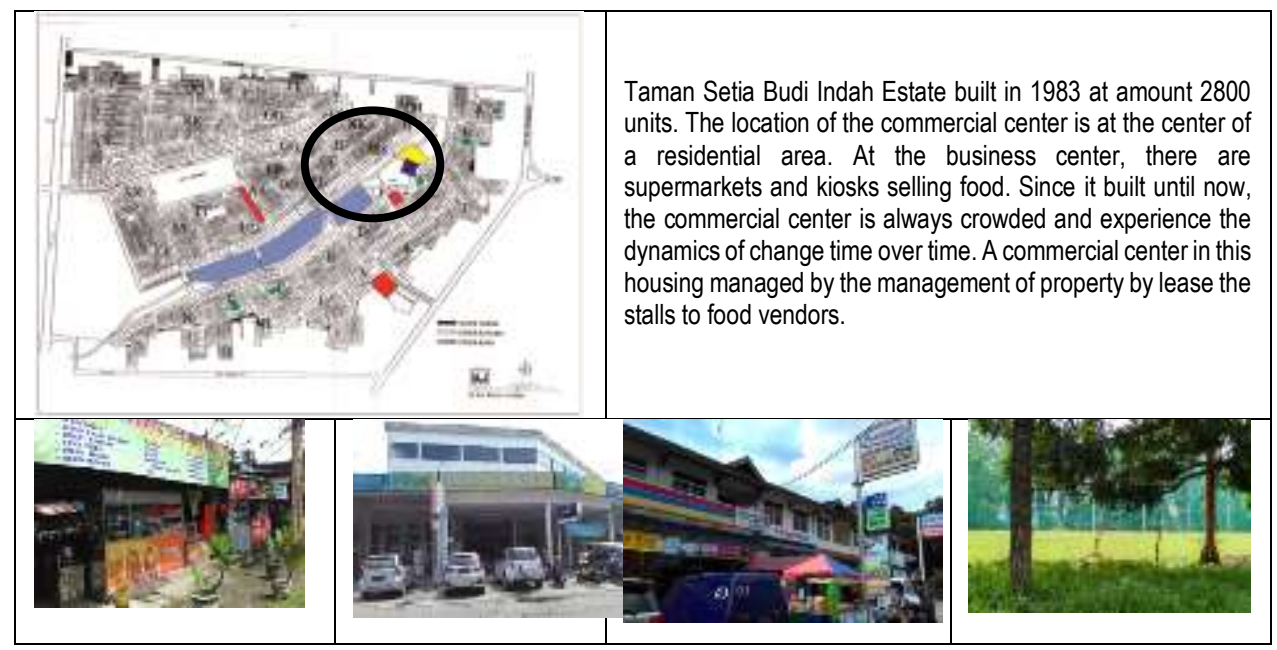

Figure 5. The situation of commercial center at Taman Setia Budi Indah Estate

Recapitulation of the distributed questionnaire in Johor Indah Permai Estate shows 100\% of the people know the existence of the mosque (Figure 6). But there are $21 \%$ of the people who have never been there (Figure 7). Suspected that this group is not Moslems or they do not worship in a mosque or not to worship at all. But the mosque on this housing also serves as the activity center of the occupants. The result can see from Figure 8 which indicates there were $69 \%$ of the people do activities together. As in Figure 10 where the residents held Hari Raya Idul Adha or Idul Fitri. And in Figure 9 indicate that $72 \%$ of respondents were satisfied with the presence of mosques. 


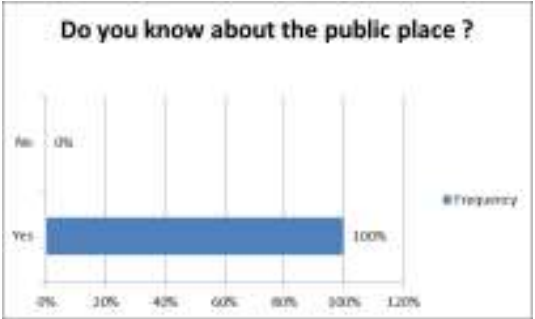

Figure 6 . Know about the mosque

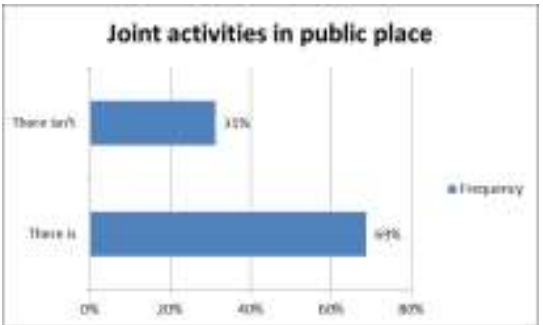

Figure 8. Joint activities

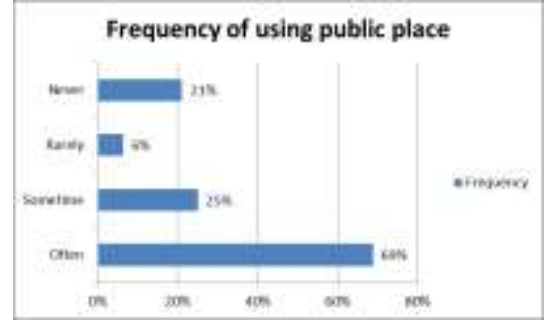

Figure 7. Frequency of using the mosque

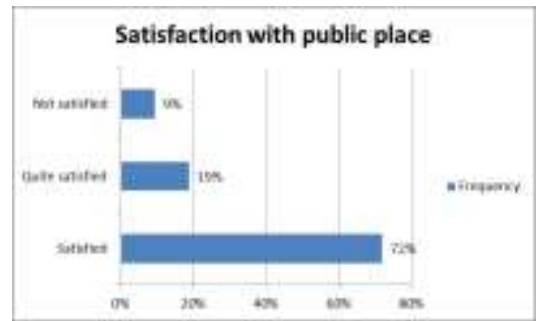

Figure 9. Satisfaction with the mosque

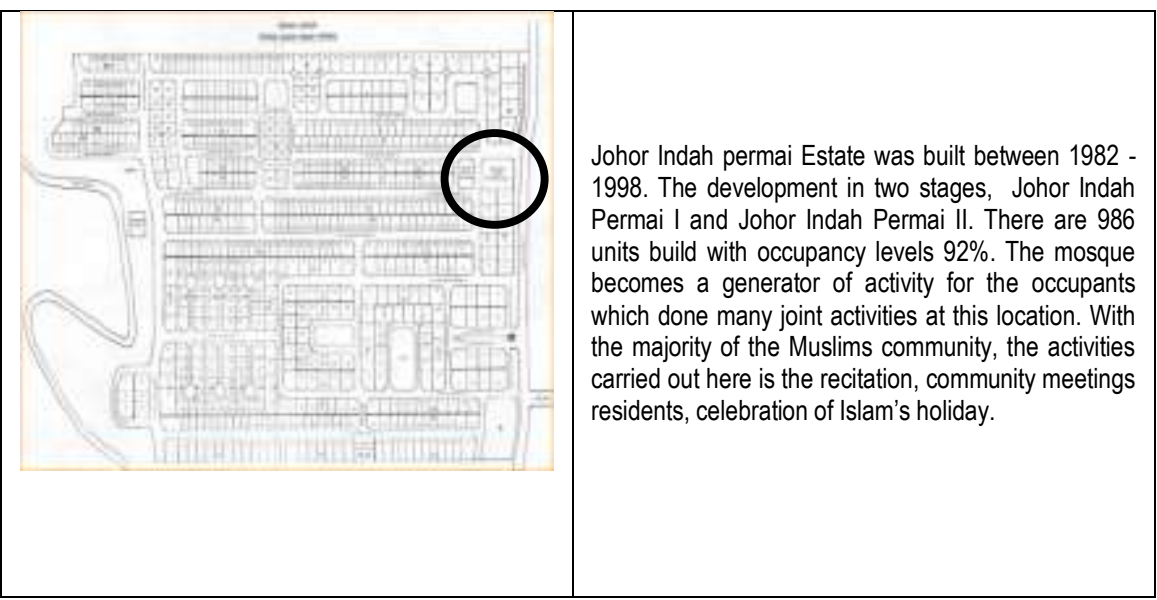




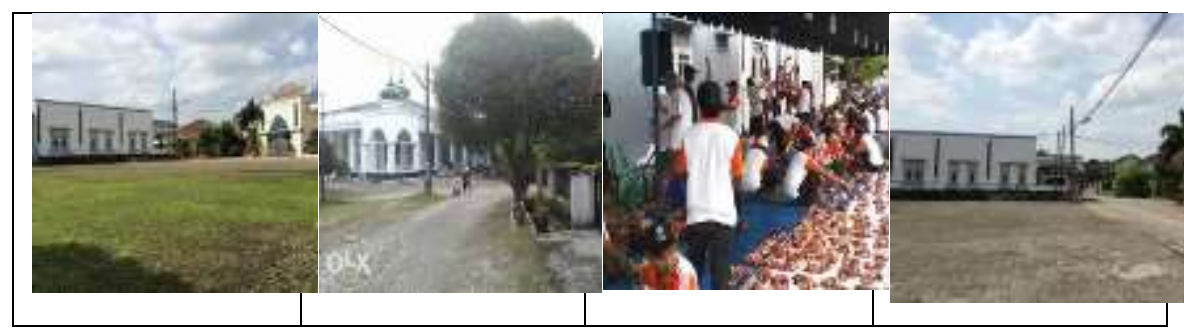

Figure 10. Mosque situation in Johor Indah Permai Estate

Research conducted by (Baharudin \& Ismail, 2014) which found that the mosque is a place to move communal Muslim worldwide. Much modern housing built now puts mosque Muslim community only as a symbol rather than to take advantage of functional community space. The design of the mosque in the residential area can also serve as a function of activity and socio-culture centers. Johor Indah Permai Estate did not have shopping facilities so that the mosque can use as a center for community Muslim in the neighborhood.

\subsection{Discussion and Analysis}

Research's results on public space and the generator housing activity analyzed based on the theory of increasing livable neighborhood. Then the evaluation will examine according to stages of shaping place's process in a residential area (Carmona, 2014) to get the achievement phase of the livable neighborhood. Based on the accomplishments of this stage are arranged the recommendation to increase livable community. The same way did on Johor Indah Permai Estate.

Table 1. Analysis Commercial Center at Taman Setia Budi Indah Estate

\begin{tabular}{ll}
\hline PLANNING & TAMAN SETIA BUDI INDAH ESTATE \\
COMPONENT & \\
\hline PUBLIC PLACES AND & $\begin{array}{l}\text { The design of commercial center in the } \\
\text { ACTIVITY }\end{array}$ \\
nENERAThborhood as the main generator of \\
activity. But the management and \\
maintenance of the business center \\
handed over to private actors as the \\
tenants The design parks and \\
commercial centers are still not \\
connected by the sidewalk. The \\
pattern of transportation in the area is \\
vehicles oriented transport
\end{tabular}

DESIGN

STRATEGIES
The sidewalk did not design hierarchically and patterned. The path built along a street pattern. The sidewalk did not connect the parks, commercial center. The connectivity should be a priority in the design of sidewalk
ANALYSIS

The environmental management of commercial centers conducted by the management property. Recommendation: The economic actors involved in management and maintenance the area.

The activities sustainable during 30 years because the commercial space is already there. But the process of shaping place should proceed again to the second stage of the design of the built environment with an attractive commercial function. (Carmona, 2014)

Preferably the sidewalk connecting any destination in the area. The sidewalk should not follow the internal road network of a motor vehicle, but it can go directly to destinations within the existing infrastructure in the housing (Larco et al., 2014) 


\begin{tabular}{|c|c|c|}
\hline & $\begin{array}{l}\text { Landscape design merely fills the open } \\
\text { space in addition to residential } \\
\text { buildings. There is not a clear } \\
\text { hierarchy between open space one } \\
\text { another. The majority of the occupants } \\
\text { use for sports activity. }\end{array}$ & $\begin{array}{l}\text { Designing landscaping should: } \\
\text { - Creating a useful open space and } \\
\text { attractive } \\
\text { - Using natural elements to create spaces } \\
\text { of privacy } \\
\text { - Creating an identity for each open space }\end{array}$ \\
\hline \multirow[t]{2}{*}{$\begin{array}{l}\text { PLANNING } \\
\text { STRATEGIES }\end{array}$} & $\begin{array}{l}\text { The housing designed with a landed } \\
\text { house types and mix use. The } \\
\text { activities of walking and cycling is not } \\
\text { a top priority. }\end{array}$ & $\begin{array}{l}\text { The pedestrian from the commercial } \\
\text { center should be connected to all } \\
\text { destinations in a residential area to make } \\
\text { the distance becomes shorter. (Larco et } \\
\text { al., 2014). }\end{array}$ \\
\hline & $\begin{array}{l}\text { Pedestrian and bicycle path into one } \\
\text { lane motor vehicle. Walkability in a } \\
\text { residential area not created. } \\
\text { Commercial center only connected to } \\
\text { the motor vehicle lanes }\end{array}$ & $\begin{array}{l}\text { Need to develop friendly bike path to other } \\
\text { destination in the area. Need to develop } \\
\text { places to put the bike safe and } \\
\text { comfortable }\end{array}$ \\
\hline $\begin{array}{l}\text { MANAGEMENT } \\
\text { STRATEGIES }\end{array}$ & $\begin{array}{l}\text { The results showed the potential of } \\
\text { socio-economic in the process of } \\
\text { shaping place }\end{array}$ & $\begin{array}{l}\text { Management property need to coordinate } \\
\text { the economic stakeholder and planning } \\
\text { joint activities periodically. (Carmona, } \\
\text { 2014). This activity will enhance the } \\
\text { economic potential and improve the social } \\
\text { link between stakeholders }\end{array}$ \\
\hline
\end{tabular}

Table 2. Analysis Community Mosque at Johor Indah Permai Estate

\begin{tabular}{|c|c|c|}
\hline $\begin{array}{l}\text { PLANNING } \\
\text { COMPONENT }\end{array}$ & JOHOR INDAH PERMAI ESTATE & ANALYSIS \\
\hline $\begin{array}{l}\text { PUBLIC PLACES AND } \\
\text { ACTIVITY } \\
\text { GENERATOR }\end{array}$ & $\begin{array}{l}\text { The placement of community mosque } \\
\text { is located in front area but do not have } \\
\text { a clear entry from the main gate } \\
\text { housing } \\
\text { City mosque has parking space for the } \\
\text { visitors. The parking area also be used } \\
\text { for activities at Muslims holiday such } \\
\text { as Idul Fitri and Idul Adha }\end{array}$ & $\begin{array}{l}\text { The appearance of Mosque quite } \\
\text { attractive because surrounded by open } \\
\text { space. Characteristics of liveable } \\
\text { communal mosque focus on } \\
\text { architectural form rather than spatial } \\
\text { organization (Baharudin \& Ismail, 2014) }\end{array}$ \\
\hline DESIGN STRATEGIES & $\begin{array}{l}\text { The placement of mosque is not at the } \\
\text { center of the residential area. Majority } \\
\text { occupants access the mosque vehicle } \\
\text { There is not planted trees surrounding } \\
\text { the mosque. The open space becomes } \\
\text { dry and reflecting solar radiation into } \\
\text { the mosque }\end{array}$ & $\begin{array}{l}\text { The communal mosque should be } \\
\text { connected by sidewalk to all destinations } \\
\text { within the area so that residents will be } \\
\text { easier to reach the mosque. } \\
\text { Landscape design around the mosque } \\
\text { should use natural elements to create a } \\
\text { more habitable development (Larco et al., } \\
\text { 2014) }\end{array}$ \\
\hline $\begin{array}{l}\text { PLANNING } \\
\text { STRATEGIES }\end{array}$ & $\begin{array}{l}\text { Pedestrian and bicycle lanes merge } \\
\text { into the lane of the vehicle. } \\
\text { Walkability in the area not created. }\end{array}$ & $\begin{array}{l}\text { Need to develop friendly bike path and } \\
\text { places to put the bikes safely and } \\
\text { comfortable. The Muslim community has } \\
\text { access to the mosque for religious } \\
\text { activity by walking or cycling. (Larco et } \\
\text { al., 2014) }\end{array}$ \\
\hline $\begin{array}{l}\text { MANAGEMENT } \\
\text { STRATEGIES }\end{array}$ & $\begin{array}{l}\text { The results showed the potential of } \\
\text { socio-economic and socio-cultural in } \\
\text { the process of shaping place. But this }\end{array}$ & $\begin{array}{l}\text { Muslim organization needs to } \\
\text { coordinated with management property to } \\
\text { improve utilization of the mosque is not }\end{array}$ \\
\hline
\end{tabular}


potential has not managed well so that the condition is not optimal only a place of worship but also as a center of social and cultural activities and education. The mosque can serve as a communal Muslim catalyst (Baharudin \& Ismail, 2014) not only for the residents but also for other housing residents around the area.

The result of discussion and analysis showed the process of increasing livable neighborhood requires a different approach depending on the socio, economic and cultural situation in the neighborhood. Characteristics of surrounding area imply opportunities on how the area would have to be treated and utilized. The shaping process for increasing liveability requires the involvement of various parties. (Pacione, 1990). These findings suggest that research into the process of shaping place to achieve a livable neighborhood remains to be done to further research in the case of another residential area.

\subsection{Conclusion}

The results of this study will contribute to the improvement of a livable neighborhood that has long inhabited. Housing has long been occupied at least have the identification of the history and tradition of the place that can use as a basis for improving the livable neighborhood. The processes of shaping place with different functions require different strategies and stakeholders as well as in the sample of the research above such as the commercial center and Mosque community. This study provides a new research direction that to increase livable neighborhood can be used the fourth planning strategies namely management strategy, planning strategy, design strategy and public place and activity generator to assess other housing types that have long inhabited.

\section{Acknowledgement}

I would like to thank to Indonesia State Ministry of Research and Technology which have provided the research grant Penelitian Unggulan Perguruan Tinggi 2016 to the researcher, so that the research can be accomplished. The highest appreciation goes to my undergraduate students in Department of Architecture, Faculty of Engineering University of Sumatera Utara which helped the researcher to collect data in the research.

\section{References}

Aulia, Dwira Nirfalini (2016) A Framework for Exploring Livable Community in Residential Environment. Case Study : Public Housing In Medan, Indonesia, Procedia - Social and Behavior Sciences, 234, pp. 336-343

Baharudin, Nurul 'Athiqah \& Ismail, Alice Sabrina (2014) Communal Mosques : Design Functionality towards the development of sustainability for community, Procedia-Social and Behavioral Sciences 153, pp. 106-120 
Benefield, Justin D (2009) Neighbourhood amenity packages, property price and marketing time, Property Management, 27 (5), pp. 348-370.

Caneparo, Luca \& Bonavero, Federica (2016) Neighbourhood regeneration at the grassroots participation : Incubators co-creative process and system, International Journal of Architectural Research, $10: 2$, pp. 204-218.

Carmona, Matthew (2014) The Place-shaping Continuum : A Theory of Urban Design Process, Journal of Urban Design, $19: 1,2-36$.

Chiang, Chia-Ling; Liang, Jeng-Jong (2013) An evaluation approach for livable urban environment, Environment Science Pollution Research, 20 : 5229-5242.

Cinar, Eylem Akman; Cubukcu, Ebru (2013) Micro Scale Environmental Characteristics and Fear of Crime, Asian Journal of Environment-Behavior Studies, 4 (11), pp. 75-85

Conteh, Fodei M; Oktay, Derya (2016) Measuring liveability by exploring urban qualities of Kissy Street, Freetown, Sierra Leone, Open House International, 41 (2), pp. 23-32.

Der Pas, Suzan van; Ramklass, Serela; O'Leary, Brian; Anderson, Sharon; Keating, Norah; Cassim, Bilkish (2015) Features of Home and Neighbourhood and yhe liveability of Older South Africans, European Journal Ageing, 12 : 215-227.

Hanna, Sonya \& Rowley, Jennifer (2013) Place brand practitioner;s perspectives on the management and evaluation of the brand experience, TPR, 84(4), pp. 473-495.

Kim, Jae Hong; Pagliara, Francesca; Preston, John (2005) The Intention to Move and Residential Location Choice Behavior, Urban Studies, 42 (9), pp. 1621-1636

Kozaryn, Adam Okulicz (2013) City Life : Rankings (Livability) Versus perceptions (Satisfactions), Social Indicator Research, 110 : 433-451

Larco, Nico; Kelsey, Kristin; West, Amanda (2014) Site Design for Multifamily Housing, Island Press, New York McCann, J Eugene (2008) Livable City/Unequal City : The Politics of Policy Making in a Creative Boomtown, Revue Interventions Economiques 37, pp.1-19

Pacione, M (1990) Urban livability : A review, Urban Geography, Vol.11, pp 1-30

Pacione, Michael (2009) Urban Geography. A Global Perspective, $3^{\text {rd }}$ edition, Routledge, New York 